\title{
How acceptable is the HIV/AIDS self-testing among women attending immunization clinics in Effurun, Southern Nigeria
}

Wasiu Olalekan Adebimpe, PhD, FWACP'1, Dora Ebikerne Ebikeme, BSc, MPH², Olubukunola Omobuwa, MPH, FWACP ${ }^{3}$, Edward Oladejo, BSc, MSc $^{4}$
ABSTRACT

HIV testing remains the gateway to HIV/AIDS prevention, treatment, care, and support interventions. In Nigeria, a significant proportion of the populations do not know their HIV status. HIV self-testing done without the help of a healthcare provider could remove identified barriers to HIV testing and close gaps in HIV treatment and prevention cascades. This study set out to assess the knowledge and acceptability of HIV self-testing (HIVST) among women of childbearing age attending immunization clinics in Effurun, Nigeria. A descriptive, cross-sectional study was conducted among 357 women of child-bearing age selected using multistage sampling technique.

Research instrument used was a semi-structured, interviewer-administered pre-tested questionnaire. Data was analyzed using the SPSS software version 23.0. Mean age of respondents was $33.6( \pm 7.3)$ years. Of the respondents, $286(80.1 \%)$ were aware of HIV self-testing; electronic media followed by health care workers were the common sources of information. About $83(23.0 \%)$ had good while $274(76.8 \%)$ had poor mean knowledge score of HIVST. Two hundred and seventy-eight (77.9\%) ever thought one could do the HIV test at home by oneself, $306(86.0 \%)$ accepted to conduct the test on themselves if they had the opportunity while 51 (14.0\%) said they would not. On binary logistic regression, identified predictors of accepting HIVST among the respondents included being older, educated, and married. It was concluded that a high knowledge level and acceptability of HIVST among the study respondents lends support to the fact that that the procedure should be promoted in the stakeholders' efforts to improve HIV testing among the general population.
Author affiliations are listed at the end of this article.

Correspondence to: Wasiu Olalekan Adebimpe, PhD, FWACP University of Medical Sciences lekanadebimpe@gmail.com

\section{KEYWORDS}

HIV Self Testing, Knowledge, Acceptability, Women of Reproductive Age group, Nigeria

\section{INTRODUCTION}

In Nigeria, like in many other parts of the world, access to and uptake of HIV testing and counseling (HTC) services have significantly increased over the past decade. However, a significant proportion of people at high risk still do not know their status. ${ }^{1}$ One of the reasons for the poor coverage of the conventional health facility-based counseling and testing is the refusal to test due to the fear of societal stigma and discrimination that may result from a positive HIV test result, ${ }^{2}$ and the fear of coping with a disease which up till the present has no known cure but capable of negatively affecting the quality of life of those infected.

Nigeria has identified the need to scale-up HIV Counseling and Testing (HCT), including the potential of a self-testing methodology. ${ }^{3} \mathrm{~A}$ study has attested to HIV self-testing (HIVST) as a cost effective intervention for the prevention of HIV transmission. ${ }^{4}$ A health system with adequate policy document and formal guidance on HIVST with the five Cs of HTC (consent, confidentiality, counseling, correct results and connection) is a panacea for effective HIV care, treatment and prevention. ${ }^{5}$ It is also important to conduct more research to provide evidence that HIVST is a viable option at the national level. As 
an entry point, HIV self-testing can be done in the absence of a healthcare provider and it may help close some gaps in the HIV treatment and prevention cascades.

Self-testing could inform early decisions by vulnerable members of the population to access the appropriate care and preventive services including referrals for other required health services. The use of such technology, whether employing saliva, urine or other body fluids as applicable for home testing should be standardized and less complex, thereby building the knowledge and attitude capacity of the population on the methods. It would also institutionalize a tactical and streamlined post test disclosure mechanism, thereby removing barriers that were known to be associated with institution based HCT. HIVST is not yet popular in Nigeria while authors felt that it would be a welcome development to the general population. This study therefore assessed the awareness, knowledge and acceptability of HIV self-testing among women of child-bearing age attending immunization clinics in secondary health facilities in Effurun, Delta State, in South Nigeria.

\section{METHODOLOGY}

STUDY AREA

Effurun is the headquarters of the Uvwie Local Government Area of Delta state Nigeria, with a population of 114,951 according to a recent projection of the last national census. ${ }^{6}$ HIV prevalence in Delta state, Nigeria is slightly higher than the national average of 5.1\%.7 There are a tertiary, a secondary and numerous private hospitals and primary health care facilities providing HIV and related services within the study area.

\section{STUDY DESIGN}

Study is health facility-based descriptive, crosssectional survey.

StUDY POPULATION

Study population includes all women of reproductive age (15-49 years) attending immunization clinic (for their children) in Ekpan General Hospital, irrespective of their HIV status. Women from health facilities providing primary and tertiary healthcare services were excluded from the study, as clients attending secondary level health facilities typically represent a mix of those attending primary and tertiary level health facilities.

\section{SAMPLE SIZES}

Estimation was based on the modified Leslie Fisher's formula for population above $10,000 .{ }^{8}$ An estimated sample size of 322 was increased to 360 in order to cater for attrition and non-responses.

\section{SAMPLING METHODS}

A 2-stage sampling technique was employed in sample selection. In the first stage, two out of three immunization clinic days were selected using simple random sampling (ballot method), and research instruments were equally allocated to clinic days. In Stage 2, a list of all eligible women on a clinic day was obtained from the triage nurse on duty for the day. A systematic sampling of one in three women on the sampling frame/list was made and this continued until allocated questionnaires for that day were exhausted.

\section{RESEARCH INSTRUMENTS AND DATA COLLECTION}

A semi-structured, interviewer administered questionnaire was employed in data collection after pretesting among 20 similarly eligible women in a secondary health care facility in Lagos state. Three trained research assistants were employed to assist in data collection. A native Yoruba language version of the questionnaire was drafted by translating the questionnaire into the local language and back translated to English, and these were used to collect information from the illiterate respondents. The research instrument was also reviewed by two HIV specialists including an HIV programme clinical site manager and a former director of the Institute of Human Virology Nigeria in charge of HIV counseling and testing. Study variables include knowledge, attitude and acceptability of HIVST and their determinants. 
ETHICAL APPROVAL

Approval to conduct the study was obtained from LAUTECH Teaching Hospital Osogbo ethics review committee. Written informed consent was obtained from every respondent who agreed to participate in the study.

\section{DATA ANALYSIS}

SPSS software version 23.0 was used after data cleaning, and consistency of data checked through double data entry and checking for outlier values. Data were presented in form of charts and tables. Questions related to knowledge were scored accordingly with score of 1 allocated to each right (or correct) answer for those with "Yes" response and score 0 given to wrong (or incorrect) answer for those with "No" response. Total score on knowledge was computed and mean score determined.

Respondents with scores equal to or above the mean were classified as having adequate knowledge while those who scored below the mean score were classified as having inadequate knowledge.

The responses from attitude questions that were presented using the Likert scale (strongly agree, agree, indifferent, disagree and strongly disagree options) were scored 5,4,3,2,1 in that order for positive attitude and 1,2,3,4,5 for negative attitude. Total score was computed and mean score determined. Those that scored above the mean score were said to have favorable attitude while those below mean score were said to have unfavorable attitude. Bi-variate analysis was done using the Chi-squared test in order to determine the assciation between categorical variables, while binary logistic regression showcased association between the major outcome variables and some selected variables most especially socio-demographic. Level of significance was set at $p \leq 0.05$.

\section{RESULTS}

A total of 350 analyzable questionnaires were returned, giving a response rate of $99.2 \%$. The mean age of the respondents was $33.6( \pm 7.3)$ years. Respondents belonging to the age group $31-40$ years were 172 (48.2\%); 315 (88.2\%) were married, 265 (74.2\%) were in monogamous marriages (Table 1).

Table 2 shows that two hundred and eighty six (80.1\%) respondents were aware of HIV self testing, with television and health care workers as the most common sources of information . Only 142(39.8\%) could correctly give the definition of HIV self testing. Reasons given by the study respondents for entertaining fears of having HIV testing done through the conventional health facility-based CT include stigma, 52(14.6\%); discrimination, $121(33.9 \%)$ and fear of death since there is presently

\begin{tabular}{|c|c|c|}
\hline Variables & Frequency (n) & Percent (\%) \\
\hline \multicolumn{3}{|l|}{ Age (Mean age $=33.6 \pm 7.3$ years) } \\
\hline$\leq 20$ & 22 & 6.2 \\
\hline $21-30$ & 136 & 38.1 \\
\hline $31-40$ & 172 & 48.2 \\
\hline$>40$ & 27 & 7.5 \\
\hline \multicolumn{3}{|l|}{ Marital Status } \\
\hline Single/never married & 25 & 7.0 \\
\hline Married & 315 & 88.2 \\
\hline Separated & 2 & 0.6 \\
\hline co-habitation & 15 & 4.2 \\
\hline \multicolumn{3}{|l|}{ Educational level } \\
\hline None & 5 & 1.4 \\
\hline Primary & 25 & 7.0 \\
\hline Secondary & 21 & 5.9 \\
\hline Vocational/technical & 124 & 34.7 \\
\hline Tertiary /university & 182 & 51.0 \\
\hline \multicolumn{3}{|l|}{ Occupation } \\
\hline Civil/Public servant & 49 & 13.7 \\
\hline Trader & 165 & 46.2 \\
\hline Farmer/fishermen & 24 & 6.7 \\
\hline Artisan & 76 & 21.3 \\
\hline Unemployed & 40 & 11.2 \\
\hline Others & 3 & 0.9 \\
\hline \multicolumn{3}{|l|}{ Marriage type } \\
\hline Monogamous & 265 & 74.2 \\
\hline Polygamous & 92 & 25.8 \\
\hline
\end{tabular}

TABLE 1: Socio-demographic characteristics of respondents $(\mathrm{N}=357)$ 


\begin{tabular}{|c|c|c|}
\hline Variables & Frequency (n) & Percent (\%) \\
\hline $\begin{array}{l}\text { Are you aware of HIV self-testing? } \\
\text { Yes } \\
\text { No }\end{array}$ & $\begin{array}{r}286 \\
71\end{array}$ & $\begin{array}{l}80.1 \\
19.9\end{array}$ \\
\hline $\begin{array}{l}\text { Major source of information if yes }(\mathbf{n}=\mathbf{2 8 6}) \\
\text { Telivision/radio/newspapers } \\
\text { HCWs } \\
\text { Internet, others }\end{array}$ & $\begin{array}{r}139 \\
134 \\
84\end{array}$ & $\begin{array}{l}48.6 \\
46.9 \\
29.5\end{array}$ \\
\hline $\begin{array}{l}\text { What does HIV Self testing entail? } \\
\text { For one to carry out the test by oneself } \\
\text { Personal, privacy } \\
\text { To know one's status } \\
\text { To collect blood with lancet and place it on the HIV test strip } \\
\text { Don't know }\end{array}$ & $\begin{array}{r}142 \\
147 \\
24 \\
21 \\
23\end{array}$ & $\begin{array}{r}39.8 \\
41.2 \\
6.7 \\
5.9 \\
6.4\end{array}$ \\
\hline $\begin{array}{l}\text { What is the advantages of HIV-self testing over the } \\
\text { health facility-based HIV testing? } \\
\text { Stigma is not a problem as nobody sees you } \\
\text { Discrimination is not an issue } \\
\text { I can confidentially go to the doctor to access drug } \\
\text { I can easily refer myself to a treatment centre } \\
\text { I will not witness the bad attitude of the health care workers } \\
\text { I can keep my confidentiality } \\
\text { It have the potential to reach person who otherwise may } \\
\text { never seek testing and are at higher risk of for HIV infection }\end{array}$ & $\begin{array}{l}303 \\
288 \\
281 \\
194 \\
281 \\
306 \\
279 \\
195\end{array}$ & $\begin{array}{l}84.9 \\
80.7 \\
78.7 \\
54.3 \\
78.7 \\
85.7 \\
78.2 \\
54.6\end{array}$ \\
\hline $\begin{array}{l}\text { Confusion is bound to happen in HIVST e.g. false results } \\
\text { Yes } \\
\text { No }\end{array}$ & $\begin{array}{l}147 \\
210\end{array}$ & $\begin{array}{l}41.2 \\
58.8\end{array}$ \\
\hline $\begin{array}{l}\text { It is always good to retest \& confirm HIVST results later } \\
\text { Yes } \\
\text { No }\end{array}$ & $\begin{array}{r}284 \\
73\end{array}$ & $\begin{array}{l}79.6 \\
20.4\end{array}$ \\
\hline $\begin{array}{l}\text { What do you think are the main fears of having an HIV } \\
\text { test done in the health facility? } \\
\text { Stigmatization } \\
\text { Discrimination } \\
\text { Fear of death } \\
\text { Fear of husband's anger } \\
\text { Others }\end{array}$ & $\begin{array}{r}52 \\
121 \\
154 \\
15 \\
15\end{array}$ & $\begin{array}{r}14.6 \\
33.9 \\
43.1 \\
4.2 \\
4.2\end{array}$ \\
\hline $\begin{array}{l}\text { What specimen do you think should be used for HIVST? } \\
\text { Blood } \\
\text { Saliva } \\
\text { Plasma } \\
\text { Oral fluid }\end{array}$ & $\begin{array}{r}146 \\
55 \\
109 \\
34 \\
\end{array}$ & $\begin{array}{r}40.9 \\
15.4 \\
30.5 \\
9.5 \\
\end{array}$ \\
\hline
\end{tabular}

TABLE 2: Respondents' level of knowledge on HIV self-testing ( $N=357$ )

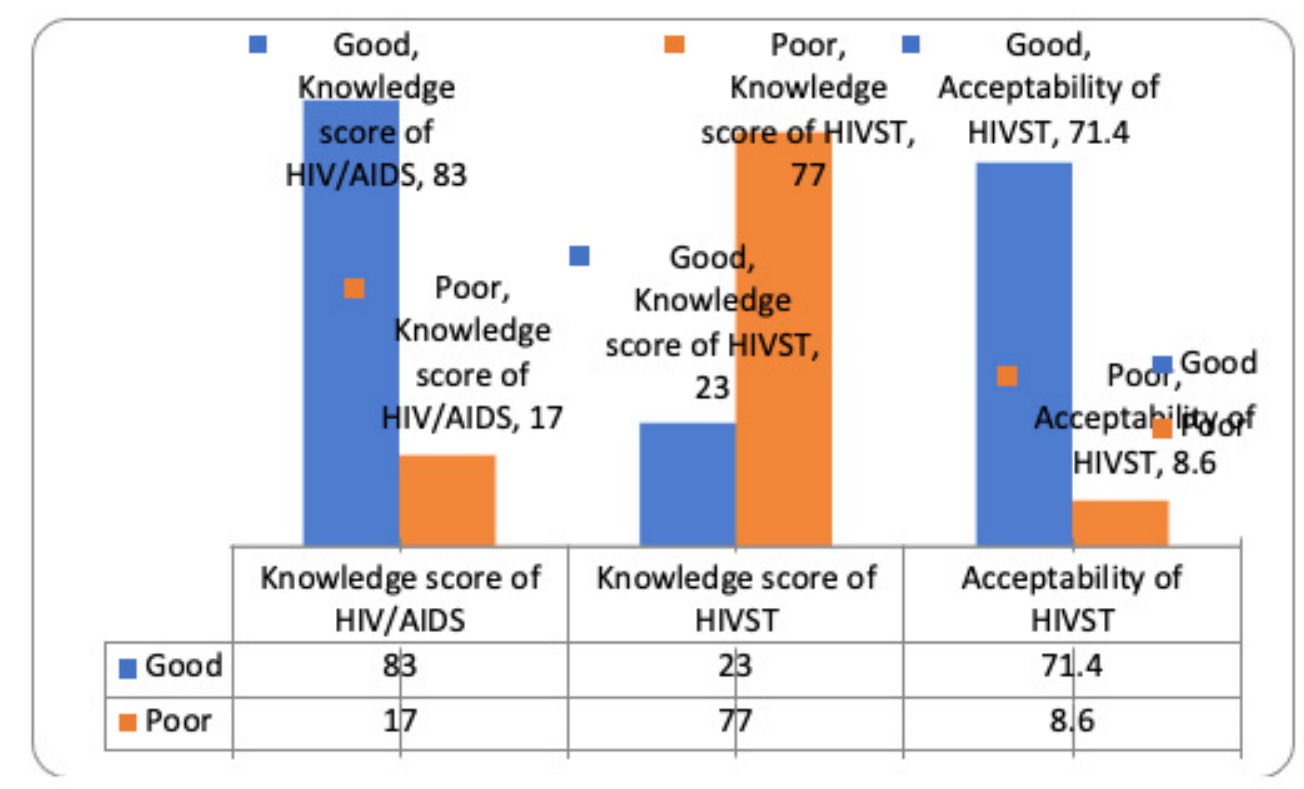

FIGURE 1: Knowledge score of HIV/AIDs and HIVST, and acceptability score of HIVST 


\begin{tabular}{|c|c|c|}
\hline \multirow{2}{*}{\multicolumn{3}{|c|}{\begin{tabular}{|l} 
Variables \\
Have you been tested for HIV/AIDS?
\end{tabular}}} \\
\hline & & \\
\hline Yes & 271 & 75.9 \\
\hline No & 86 & 24.1 \\
\hline \multicolumn{3}{|l|}{ If no to above question, do you plan doing it? $(\mathrm{n}=86)$} \\
\hline Yes & 52 & 60.5 \\
\hline No & 34 & 39.5 \\
\hline \multicolumn{3}{|l|}{ If yes, where was it conducted? } \\
\hline Health facility nearer to your house & 208 & 76.8 \\
\hline Health facility nearer to your place of work & 38 & 14.0 \\
\hline At home by a health care worker & 25 & 9.2 \\
\hline \multicolumn{3}{|l|}{ Have your current partner been tested for HIV/AIDS? } \\
\hline 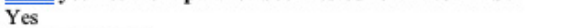 & 116 & 32.5 \\
\hline No/ Don't know & 241 & 67.5 \\
\hline \multicolumn{3}{|l|}{ Do you think you can do this Hiv test at home by yourself? } \\
\hline Yes & 278 & 77.9 \\
\hline No & 79 & 22.1 \\
\hline \multicolumn{3}{|l|}{$\begin{array}{l}\text { Will you accept doing it at home by yourself without health } \\
\text { worker counseling? }\end{array}$} \\
\hline Yes & 255 & 71.4 \\
\hline No & 102 & 28.6 \\
\hline \multicolumn{3}{|l|}{$\begin{array}{l}\text { Would you prefer to do the test alone in the absence of } \\
\text { significant others e.g., HCWs, spouse etc? }\end{array}$} \\
\hline Yes & 284 & 79.6 \\
\hline No & 73 & 20.4 \\
\hline \multicolumn{3}{|l|}{$\begin{array}{l}\text { Is doing HIV test yourself without been counseled a good } \\
\text { thing for the health systems? }\end{array}$} \\
\hline Yes & 164 & 45.9 \\
\hline No & 193 & 54.1 \\
\hline \multicolumn{3}{|l|}{ There is possibility of a false positive or false negative results } \\
\hline No & 207 & 58.0 \\
\hline \multicolumn{3}{|l|}{$\begin{array}{l}\text { Are you willing to disclose the outcome of your self } \\
\text { performed home HIV testing? }\end{array}$} \\
\hline Yes & 265 & 74.2 \\
\hline No & 92 & 25.8 \\
\hline \multicolumn{3}{|l|}{ Would you recommend HIV self-testing service to others? } \\
\hline Yes & 300 & 84.0 \\
\hline No & 57 & 16.0 \\
\hline
\end{tabular}

TABLE 3: Acceptability of HIV self testing service by the respondents $(\mathrm{N}=357)$

\begin{tabular}{|c|c|c|c|c|c|c|c|c|}
\hline \multirow{3}{*}{ Variables } & \multicolumn{4}{|c|}{ Bi-variate Analysis } & \multicolumn{4}{|c|}{ Binary Logistic Regression } \\
\hline & \multicolumn{2}{|c|}{$\begin{array}{l}\text { Knowledge on HIV } \\
\text { self-testing }\end{array}$} & \multirow[t]{2}{*}{$x^{2}$} & \multirow[t]{2}{*}{ P-value } & \multirow[t]{2}{*}{ OR } & \multicolumn{2}{|c|}{$95 \% \mathrm{Cl}$} & \multirow[t]{2}{*}{$\rho$-value } \\
\hline & Good & Poor & & & & Lower & Upper & \\
\hline $\begin{array}{l}\text { Age(years) } \\
<30 \\
31 \text { and above }\end{array}$ & $\begin{array}{r}29(9.1) \\
54(27.1)\end{array}$ & $\begin{array}{r}29190.9) \\
145(72.9)\end{array}$ & 6.46 & 0.09 & 3.73 & 2.28 & 6.11 & 0.01 \\
\hline $\begin{array}{l}\text { Marital status } \\
\text { Single/never married } \\
\text { Ever Married }{ }^{*}\end{array}$ & $\begin{array}{r}74(77.9) \\
9(3.4) \\
\end{array}$ & $\begin{array}{r}21(22.1) \\
253(96.6) \\
\end{array}$ & 9.33 & 0.02 & 0.01 & 0.00 & 0.02 & 0.01 \\
\hline $\begin{array}{l}\text { Educational level } \\
\text { None \& Primary } \\
\text { Secondary and above }\end{array}$ & $\begin{array}{l}18(60.0) \\
65(19.9)\end{array}$ & $\begin{array}{r}12(40.0) \\
262(80.1)\end{array}$ & 45.01 & $<0.001$ & 0.16 & 0.07 & 0.36 & 0.01 \\
\hline $\begin{array}{l}\text { Family type } \\
\text { Monogamous } \\
\text { Polygamous }\end{array}$ & $\begin{array}{r}5(1.9) \\
83(90.2) \\
\end{array}$ & $\begin{array}{r}260(98.1) \\
9(9.8)\end{array}$ & 31.49 & $<0.001$ & 0.89 & 1.56 & 4.99 & 0.01 \\
\hline \multirow[t]{2}{*}{ Variables } & \multicolumn{2}{|c|}{$\begin{array}{l}\text { Acceptability of } \\
\text { HIV/AIDs self-testing }\end{array}$} & \multirow[t]{2}{*}{$x^{2}$} & \multirow[t]{2}{*}{\begin{tabular}{|l|} 
P-value \\
\end{tabular}} & \multirow[t]{2}{*}{ OR } & \multicolumn{2}{|c|}{$95 \% \mathrm{Cl}$} & P-value \\
\hline & Yes & No & & & & Lower & Upper & \\
\hline $\begin{array}{l}\text { Age(years) } \\
<30 \\
>30^{\circ}\end{array}$ & $\begin{array}{l}137(86.7) \\
169(84.9)\end{array}$ & $\begin{array}{l}21(13.3) \\
30(15.1)\end{array}$ & 2.22 & 0.52 & 0.16 & 0.63 & 2.11 & 0.31 \\
\hline $\begin{array}{l}\text { Marital Status } \\
\text { single/never married } \\
\text { Ever married }\end{array}$ & $\begin{array}{r}25(80.6) \\
281(86.2) \\
\end{array}$ & $\begin{array}{r}6(19.4) \\
45(13.8) \\
\end{array}$ & 9.39 & 0.02 & 0.67 & 0.25 & 1.71 & 0.20 \\
\hline $\begin{array}{l}\text { Educational level } \\
\text { None \& primary } \\
\text { secondary }\end{array}$ & $\begin{array}{r}26(63.4) \\
280(88.6) \\
\end{array}$ & $\begin{array}{l}15(36.6) \\
36(11.4)\end{array}$ & 5.93 & 0.31 & 0.22 & 0.10 & 0.45 & 0.01 \\
\hline $\begin{array}{l}\text { Family type } \\
\text { Monogamous } \\
\text { Polygamous }\end{array}$ & $\begin{array}{r}228(86.0) \\
78(84.8) \\
\end{array}$ & $\begin{array}{l}37(14.0) \\
14(15.2)\end{array}$ & 0.08 & 0.44 & 1.11 & 0.56 & 2.15 & 0.37 \\
\hline
\end{tabular}

TABLE 4: Relationship between respondents' socio-demographic characteristics and knowledge and acceptability of HIV self-testing 
no known cure for HIV 154(43.1\%). Very few of them 55(15.4\%) and 34(9.5\%) knew that saliva and urine could be used for HIV self testing.

Figure 1 shows that 274 (77.0\%) had poor knowledge about HIV/AIDs self testing while $83(23.0 \%)$ had good knowledge; 187 (52.0\%) of the respondents had good attitude while 170 (48.0\%) had poor attitude towards HIV self-testing.

Table 3 shows that two hundred and seventy eight (77.9\%) respondents ever thought one could do this HIV test at home by oneself, 306 (86.0\%) agreed that they would carry out the test by themselves if the opportunity came along while $51(14.0 \%)$ said they would not. Three hundred (84.0\%) said they would be willing to introduce HIV self testing to others.

Table 4 shows that there was a statistically significant association between knowledge of HIV self-testing and marital status, educational status and family type $(p<0.05)$. Respondents younger than 30 years of age were about three and a half times more likely to have good knowledge of HIV self-testing compared to those 30 years and older, a finding which is statistically significant (OR 3.73, OR 2.2819$6.1198, p$ 0.001). However, there was no statistically significant association existing between acceptability of HIV self-testing and age, education status and family type ( $p>0.05)$. Respondents with age less than 30 years were about six (1/0.16) times less likely to accept HIVST compared to those above 30 years and this observation was found not to be statistically significant (OR 0.16, 95\% Cl 0.63-2.11, p 0.31). Single/ never married respondents were about one and half (1/0.67) times less likely to accept HIVST compared to the married (OR $1.67,95 \% \mathrm{Cl} 0.25-1.71, \mathrm{p} 0.20$ ). There was no difference in the odds of accepting HIVST and family type $(\mathrm{OR}=1.1)$. Respondents with none/primary education level were $4.5(1 / 0.22)$ times less likely to accept HIVST compared with those with secondary education and this observation was found to be statistically significant (OR $0.22,95 \% \mathrm{Cl}$ $0.10-0.45, \mathrm{p} 0.01)$. Thus, the predictors of accepting a HIVST on binary logistic regression include being older, being educated, and being married.

\section{DISCUSSION}

This study aimed at determining awareness and acceptability of HIV self-testing among women attending childhood immunization clinics in a secondary healthcare facility in Effurun, southern part of Nigeria. According to the WHO in 2014, HIVST is when one collects his or her own oral fluid or blood, performs an HIV test using a rapid diagnostic test (RDT) kit and interprets it, either done alone or with someone trusted in private. ${ }^{9}$

There was good awareness of HIVST among our respondents; this supports other studies. ${ }^{10,11}$ This may be because their sources of information are electronic media, most especially television and radio, both of which are easily accessible to most homes in Nigeria. There was poor knowledge of HIVST among our respondents. This is in consonance with the findings from some studies, ${ }^{12-14}$ although with slightly varying proportions. In this study, 284 (79.6\%) said that HIVST should be done alone by the user. In a related study, most of respondents (65.6\%) indicated that they would prefer to test alone.10 In this study, 150 (42.0\%) said that there is a possibility of a false positive or negative result. A re-test after HIVST should be encouraged because of the possibility of a false positive or false negative result, most especially among illiterate and naïve users. Thus, the WHO has highlighted the importance of the message that HIVST does not provide a verified diagnosis on HIV, but requires further testing. Manufacturers should also enclose clear instructions for the use and interpretation of results. ${ }^{15}$ The need to ensure kits accuracy ${ }^{16}$ will also reduce the potential for antiretroviral (ARV) self medication following a positive HIVST results. Therefore, to reach the National Agency for the Control of AIDS (NACA) target of testing $90 \%$ of eligible population by 2020 , there is need to explore novel approaches that can drive the uptake of HCT by the general population in Nigeria.

Acceptability of HIVST was high among our respondents. This supports several other studies. ${ }^{17-21}$ In addition, HIVST acceptability has 
been high in some countries, ranging from $73 \%$ to $89 \% .{ }^{22}$ Education level as one of the predictors of acceptability of HIVST could be explained by the fact that clients who are educated are more likely to be able to read kits manufacturer's instructions and follow them appropriately during HIVST. It is therefore important that health care workers counsel the clients and give them un-hindered information to the HIVST procedure and interpretation of results. A limitation of this study was initial non-cooperation by some respondents once HIV testing was mentioned due to fear of stigma and discrimination. This was overcome by intense sensitization of prospective respondents, allaying their fears about HIV as well as telling them and reassuring them about the aims and objectives of this research.

In conclusion, a high awareness and poor knowledge but high acceptability of HIVST suggests that the health care workers have significant roles to play if the clients must do it correctly and get reliable results. Authors felt that health care workers should continue HIV counseling and discuss kits manufacturer's instruction on the technical knowhow on how to do the test correctly before clients actually go ahead with self testing. HIVST is capable of boosting the number of clients who got tested for HIV, the number with correct results and also the entry of HIV positive into HIV care, treatment and prevention, most especially in the presence of complementary health facility based HIV counseling services by health care workers.

\section{AUTHOR AFFILIATIONS}

1. University of Medical Sciences, Ondo, Nigeria

2. Ekpan General Hospital, Delta State, Nigeria

3. Osun State University, Ondo, Nigeria

4. Murphgan Resource Center, Osogbo, Nigeria

\section{REFERENCES}

1. Ayesha BMK, Quarraisha AK. HIV Infection and AIDS in Sub-Saharan Africa: current status, challenges and opportunities. Open AIDS J. 2016;10:34-48.

2. Kitara DL, Aloyo J. HIV/AIDS stigmatization, the reason for poor access to HIV counseling and testing (HCT) among the youths in Gulu (Uganda). African Journal of Infectious Disease. 2012;6(1):12-20.

3. Indravudh PP, Choko AT, Corbett EL. Scaling up HIV self-testing in sub-Saharan Africa: a review of technology, policy and evidence. Current Opinion in Infectious Diseases. 2018;31(1):14-24.

4. Cambiano V, Ford D, Mabugu T. Assessment of the potential cost-effectiveness of HIV selftesting in resource limited settings. Presented at 21 st Conference for Retrovirus and Infections. Boston, MA, USA; 3-6 Mar 2014.

5. World Health Organization, UNICEF, UNFPA and The World Bank. Trends in Maternal Mortality:1990-2010. WHO, UNICEF, UNFPA and The World Bank estimates. Geneva:World Health Organization; 2012.

6. National Population Commission. The 2006 National Census preliminary results. NPC Abuja Nigeria 2006.

7. Federal Ministry of Health/NACA, National HIV/ AIDs and Reproductive Health Survey (NARHS); 2015. FMoH/NACA Nigeria.

8. 8. Araoye MO. Research methodology with statistics for health and social sciences. Ilorin, Nigeria: Nathadex Publishers. 2004:117-120.

9. World Health Organization (WHO). March 2014 supplement to the consolidated guidelines on the use of antiretroviral drugs for treating and preventing HIV infection, recommendations for a public health approach. Geneva: WHO. 2014:1217.

10. Young SD, Daniels J, Chiu CJ, Bolan RK, Flynn RP and Kwok J. Acceptability of using electronic vending machines to deliver oral rapid HIV self-testing kits: A qualitative study. PLoS One. 2014;9(7):1-6.

11. Harichund C, Moshabela M, Kunene P, Abdool Karim Q. Acceptability of HIV self-testing among men and women in KwaZulu-Natal, South Africa. AIDS Carem. 2019; 31(2):186-192.

12. Heard AC, Brown AN. Public readiness for HIV self-testing in Kenya. AIDS Care. 2016;28(12):1-6.

13. Mokgatle MM, Madiba S. High acceptability of HIV self-testing among technical vocational education and training college students in Gauteng and North West Province: What are the implications for the scale up in South Africa? PLoS One. 2017;12(1):e0169765.

14. Pal K, Ngin C, Tuot S, Chhoun P, Ly C, Chhim S. 
Acceptability study on HIV self-testing among transgender women, men who have sex with men, and female entertainment workers in Cambodia: a qualitative analysis. PLoS One. 2016;11(11):1-10.

15. Kalibala S, Tun W, Muraah W, Cherutich P, Oweya E, Oluoch P.'Knowing myself first': feasibility of self-testing among health workers in Kenya'. Nairobi: population council. 2011.

16. Brown B, Folayan MO, Imosili A, Durueke F, Amuamuziam A. HIV self-testing in Nigeria: public opinions and perspectives. Global Public Health: An International Journal for Research, Policy and Practice 2014. Accessed Jan 15 2019; Available at https://www.researchgate.net/ publication/265342326_HIV_self-testing_in Nigeria Public opinions and perspectives.

17. Izizag BB, Situakibanza H, Mbutiw T, Ingwe R, Kiazayawoko F, Nkodila A et al. Factors associated with acceptability of HIV self-testing (HIVST) among university students in a Peri-Urban area of the Democratic Republic of Congo (DRC). The Pan African Medical Journal. 2018;31:248.

18. Bustamante MJ, Konda KA, Davey DJ, León SR, Calves GM, Salvatierra J. HIV self-testing in Peru: questionable availability, high acceptability but potential low linkage to care among men who have sex with men and transgender women. International Journal of STD \& AIDS. 2016;17:2093-2099.

19. Pant Pai NP, Behlim T, Abrahams L, Vadnais C, Shivkumar S, Pillay S. Will an unsupervised self-testing strategy for HIV work in health care workers of South Africa? A cross sectional pilot feasibility study. PLoS One. 2013;8(11):e79772.

20. Spielberg F, Critchlow C, Vittinghoff E, Coletti AS, Sheppard $\mathrm{H}$, Mayer KH et al. Home collection for frequent HIV testing: acceptability of oral fluids, dried blood spots and telephone results. AIDS. 2000; 14(12):1818-1829.

21. Osmond DH, Catania J, Pollack L, Canchola J, Jaffe D, MacKellar D et al. Obtaining HIV test results with a home collection test kit in a community telephone sample. J Acquir Immune Defic Syndr. 2000; 24(4):363-368.

22. Mavedzenge SN, Baggaley R, Corbett EL. A review of self-testing for HIV: research and policy priorities in a new era of HIV prevention. Clinical Infectious Diseases. 2013; 57(1):126-138. 